Article

\title{
Enabling Factors and Strategies for the Transition Toward a Circular Economy (CE)
}

\author{
Claudia Aparecida de Mattos * and Thiago Lourenço Meira de Albuquerque \\ Production Engineering Department, Centro Universitário da FEI, São Bernardo do Campo, SP 09850-901, Brazil; \\ thiago1678@terra.com.br \\ * Correspondence: cmattos@fei.edu.br; Tel.: +55-11-4353-2900
}

Received: 25 September 2018; Accepted: 2 December 2018; Published: 6 December 2018

\begin{abstract}
This study aims to identify and analyze the enabling factors and strategies for the structuring and diffusion of a circular business model. Circular model structuring involves several actors, challenges, and barriers. In this context, the present study allows discussion of the business structure in line with the principles of circularity and can contribute by mapping the factors and strategies to be worked for business development in the circular context, providing an overview and guidance for academics, businesspeople, and professionals. Through a case study method, the research allowed identification of the factors and an in-depth understanding of the strategies and drivers of circular business models; from the empirical research, it will be possible to identify opportunities that align with what is already known, but also what may be specific to the context of emerging countries to enable the circular model.
\end{abstract}

Keywords: circular economy; business model; strategies; enabling factors

\section{Introduction}

The concept of a circular economy (CE) has gained prominence in academia, corporations, and government, but its real dissemination is still limited. There is a lack of studies that address strategies and practices guided by the principles of developing processes and products for a more rational use of natural resources, reducing their consumption or promoting their recovery. From the beginning of the Industrial Revolution, productive economy has been based on a linear economy (extract, produce, and discard) [1]. The authors of [2] discuss circular economy as a sustainable alternative in the face of the linear economy model, primarily by the reuse of materials in new products. From the middle of the last century, the concept of "circular economy" has become more important for academia, industry, and government. CE includes "closing material loops", which aim for a more conscious use of natural resources and the reuse and recycling of biological nutrients to extract their maximum value with the least expenditure [3-8].

The development of business models in the context of circular economy is gaining increasing prominence in the academic, corporate, and government environments, according to what was discussed by [9-11].

Based on [12], changing to a circular economy requires an integrated vision that focuses on long-term change or transition. Thus, the change to a circular economy will lead to new business models and value chains. Consequently, this affects the design, production, use, and disposal processes, as well as the collection of products and materials for reuse. The authors of [13] argue that a deep understanding of business models will be necessary for future projects if the private sector is responsible for the transition toward a circular economy. According to $[11,14,15]$, the design and management of sustainable business models is an important area, but still insufficiently studied, constituting a gap in research. Starting from this gap, the guiding question of the present research was 
formulated: What are the enabling factors and strategies of a circular business model, and how do we structure such a model?

Based on this question, the general objective was to identify and analyze feasibility factors and strategies for structuring and disseminating a circular business model. Through a case study method, the research allowed the identification of the factors and an in-depth understanding of the strategies and drivers of circular business models, as well as identification of opportunities that align with what is already known, but also what may be specific to the context of emerging countries to enable the circular model.

\section{Circular Economy Concepts}

Although it is a contemporary movement, the circular economy is based on studies carried out since 1990, according to studies of authors such as [16]. Circular economy is a sustainable alternative in the face of the linear economy model, primarily by the reuse of materials in new products [2].

The author of [17] mentions that the guiding principle of the circular economy is referred to as the "3Rs" (reuse, repair, and remanufacturing), which have a local or regional dimension and are capable of avoiding or reducing packaging, transportation costs, and transaction costs through property maintenance. The 3Rs principle can be integrated into three additional principles developed by the author of [3]. The first, appropriate design, stresses the importance of the design phase in finding solutions to avoid waste discharge to landfills: "The products are designed for a cycle of disassembly and reuse." The second presents a reclassification of materials as "technical" and "nutrients". Technical materials (such as metals and plastics) are designed to be reused at the end of the lifecycle, while nutrients (or biological nutrients), which are generally nontoxic, "can return safely to the biosphere or on a cascade of consecutive uses". The third additional principle, "renewable", puts renewable energy as the main source of energy for the circular economy, to reduce dependence on fossil-fuel energy and improve the adaptability (resilience) of the economic system.

Some definitions confuse circular economy with recycling, while the link with sustainable development (particularly social equity) is little explored [13]. The authors, based on this systematic review, defined circular economy as an economic system that replaces the concept of "end of life" by reduction, alternative reuse, recycling, and recovery of materials in the production/distribution and consumption processes.

\subsection{Transition toward the Circular Economy Model}

The circular economy is challenging and requires a comprehensive discussion of its support and enabling mechanisms. Throughout the literature [16,17], it is observed that the interest in research in the area of circular economy has occurred at different scales: Micro (e.g., enterprise or consumer), meso (e.g., eco-industrial park), and macro (regional, cities). Authors as [16], through a detailed literature review, drew up a framework on different topics and categories that converge to the study of the circular economy model. Based on this framework, models of circular economy and their respective levels of implementation (each circular economy model has its own policies of implementation) explain these different scales. On the micro-level scale (business or consumer), the implementation is divided into models of production levels, cleaner production, consumer-level models such as green consumption (e.g., eco-label), and waste management. On the meso-level implementation (eco-industrial parks), this division occurs at levels of eco-industrial systems, district symbiosis, and industrial networks [16]. On the meso-level implementation (eco-industrial parks), this division occurs at levels of eco-industrial systems, district symbiosis, and industrial networks. Industrial systems, industries that operate as separate entities, establish an exchange of resources (materials, water, energy, and byproducts) called "industrial symbiosis" [16].

According to [17], it is important to leverage knowledge of the design of circular business models to stimulate and ensure the application of the circular economy on a micro level, encouraging factories 
and producers to adopt cleaner production $(\mathrm{CP})$ to promote the transition from a linear chain to the concept of a circular chain.

The authors of $[18,19]$ mentioned that there have been many studies related to business models bringing definitions, components, taxonomies, conceptual models, design methods and tools, adoption factors, valuation models, and change methodologies. The authors of [20] combine ideas from many authors and describe business models as conversion resources and capabilities for economic value: Business model in which value creation is based on the economic value obtained by reusing a product for the production of new offerings [21]. A sustainable business model is described as "a business model that creates value through superior customer value and contributes to the sustainable development of business and society" [22].

The authors of [14] discuss the definition of business models for sustainability and suggest three elements:

(1) How to define value proposition

(2) How to create and deliver value

(3) How to capture value and maintain or regenerate natural, social, and economic capital beyond its organizational boundaries

Deploying a successful circular economy involves constructing a business model [23]. Six key areas of integration for constructing and developing a business model in the context of circular economy are [24]:

(1) Sales model

(2) Product design/material composition: this concerns the way products are designed to reuse their components and materials

(3) IT management/data: enabling resource optimization requires a key competence, namely the ability to track products, components, and materials

(4) Maximizing the use of recycled materials/components in order to obtain the value of products, components, and materials' flow

(5) Operations strategy: building trusted partnerships and long-term relationships with suppliers and customers, including co-creation

(6) HR/incentives: changes require adequate cultural adaptation and capacity-building, training, and rewards programs

\subsection{Enabling Factors and Circular Business Model Strategies}

\subsubsection{Enabling Factors}

Enabling factors are forces or conditions that affect business model implementation and support the activities needed for future business functionality [25]. Enabling factors can influence the degree of initiation and continuation of some type of action. Although companies can promote the development of the business model, some conditions can contribute a lot to the transition, such as:

- Education

- Legislation by governments, which can create more funding incentives by subscribing to some of the risks associated with innovative business models

- Corporate social responsibility motivation [26]

The authors of [27] carried out research with small and medium companies and highlighted the factors for developing a circular business model. These include company culture, team commitment, networking, support from the demand network, financial return, and local government support. Three most important factors for an environmentally conscious manufacturing strategy are cost, current environmental regulations, and anticipated future environmental regulations [28]. The authors 
of [27] emphasize the company's culture as a facilitating factor. The mentality and commitment of staff are important aspects in facilitating the transition to a circular economy model. For startups, it is relatively easy to adopt principles of the circular economy, as the company culture develops from scratch, which may be easier than changing practices in existing businesses. The network, in a broader sense, is mentioned as a facilitator by a third of small to medium-size enterprises (SMEs). In many cases, this involves joining a group of SMEs with similar ideas, seeking sustainability, or joining a supply chain partnership. The authors of [29] highlighted the main challenges of the transition to a circular business model: as it is a change for both the organization and individuals, restructuring implies cost and resistance to risk among managers.

Geographical proximity represents an enabling factor and can promote industrial symbiotic practices with collaboration and synergy, as mentioned by the author of [30]. Considering that industrial symbiosis practices often occur at the process and manufacturing level and benefit from firms located within a certain geographic area, "extending the value of resources" often occurs at the product level, in close geographic areas. CE requires actors to work together and solve collective problems. The success of industrial symbiosis is based on companies working collectively and collaboratively with the common purpose of mutual economic and environmental sustainability [31].

\subsubsection{Business Model Circular Strategies}

The strategy for companies that are in operation to make the transition to a circular economy can be used when opening parallel business models to the traditional, as a way of entering this market.

- Industrial Symbiosis

Industrial symbiosis becomes possible when physical byproduct exchanges happen among enterprises, within and between different industries. It may be an important strategy in realizing the "zero waste in landfills" vision. The success of industrial symbiosis is based on companies that work collectively and collaboratively with the common purpose of mutual economic and environmental sustainability. Industrial symbiosis is a process-oriented solution aimed at transforming waste from one process into input or raw material for another process or product line [32].

- Extending the Resource Value

"Extending the resource value" is about collecting or sourcing "wasted" materials and resources in order to transform them into new forms of value. Studies conducted by the authors of $[22,33]$ discuss feasibility factors for exploiting the residual value of resources. According to [34], one of the strategies of the circular economy is to extend the useful life of the product. One of the actions is related to reducing the dismantling time and related costs, as they increase the viability of the extension of the useful life of the product and consequently increase the viability of the circular economy in industrialized regions. In addition, the dismantling of recycling potential and the purity of precious metals, metals, and plastics are critical.

\section{- Reverse Supply Chain}

The supply chain is a critical unit of action for the implementation of a circular economy model because of the need for a joint effort "beyond organizational boundaries" that involves coordinating upstream partners to obtain environmentally friendly inputs and downstream partners to cooperate with the adoption of environmental management practices, such as return, reuse, and recycle [35]. Implementing a circular business model encourages the design of circular or reverse supply chains, allowing products at the end of their life cycle to reenter the supply chain as production inputs through recycling, reuse, or remanufacturing [36]. In addition, according to [36], points such as the effective collaboration between chains and sectors become imperative for the establishment of a large-scale circular system. The literature highlights several challenges associated with the implementation of collaboration, such as the difficulty of coordinating responsibilities for costs and dependencies between 
activities [37], as well as information coordination, understanding how information flows along the supply chain, and how data are collected and shared among stakeholders. From the perspective of collaboration, it is fundamental to define the level of proximity, knowledge, and information that must be shared among the participants and the construction of a technological infrastructure. The dynamic understanding of how certain factors of collaborative supplier-buyer innovation (i.e., supply chain conditions, power balance, and shared vision) and complex aspects of product design determine the speed and quantity of circular products on the market is important [38]. Aligning supply chains with the principles of the circular economy have become an important strategy for organizations to work in the context of the circular economy [39].

The authors of $[40,41]$ argue that one of the most important components of circular business models is the reverse logistics of the supply chain. Rashid et al. (2013) [42] describe the circularity in business models and supply chains as a precondition for sustainable production, which in turn is necessary for the best economic and environmental performance of industrialized and developing countries.

\section{- Design of Products and Services}

Demonstrating practices provides better prospects for dissemination and adoption of circular models. The authors list lessons learned from the experience of Indian companies and highlight the following factors [43]:

(1) Integrated design with reverse logistics

(2) In relation to value delivery, companies need to design distribution channels depending on the target segment

(3) Co-creation

(4) Feasibility of repurposing end-of-life

The choice of distribution channels ranges from creating an online e-commerce platform and retail stores to building a network of local institutions and individuals to reach the last mile. Studies were conducted by [22] on design as an enabling factor to promote the transition to a circular model [44].

Products need to be designed to close "loops" and tailored to generate revenue, supported by low-cost return chains and reprocessing structures, as well as effective policies and regulations. Repurposing e-waste, which was designated as a representative design strategy in certain circumstances and has been described as the identification of a new use for a product [45] .

- Information Technology (IT)

The authors of [46] highlight technological requirements as a key issue to enable the interactive form of supply chain collaboration. Companies need to plan their IT infrastructure in order to create collaborative sites or platforms that can connect them with different agents in the external environment, such as problem solvers or new idea creators. Technology is a facilitator [47] that can guarantee traceability, mass balance, and the proper disposal of all collected material. The authors of $[48,49]$ highlight the integration of information processing, material flows, and financial benefits in all value chains, implying a highly complex environment.

\subsection{Research Framework Proposal}

Based on the factors and strategies discussed in previous topics, we elaborate on the framework presented in Figure 1. The starting point of this framework will be to analyze how organizations can develop a circular business model, identifying the feasibility factors and respective strategies. The set of enabling factors can support the strategies to develop a circular business model by building trusted partnerships and long-term relationships with suppliers and customers. Based on a thorough business model given in [50,51], we can explain how activities are performed, what resources are used, and the routines and general vision for a business ecosystem, where it is important to understand the network 
of various stakeholders and how it achieves economic value. Analyzing previous studies related to the circular business model, we can observe strategies such as supply chain collaboration by bringing all partners together, from suppliers to designers, demolishers, and waste companies. In industrial symbiosis, geographic proximity favors exchanges and provides a greater competitive advantage. For the implementation of industrial symbiosis, the actions should consider economic analysis (check the potential return on investment for allocation of materials and people), technical analysis (available technologies), environmental analysis (identify the desired environmental parameters), and regulatory (environmental and fiscal) measures.

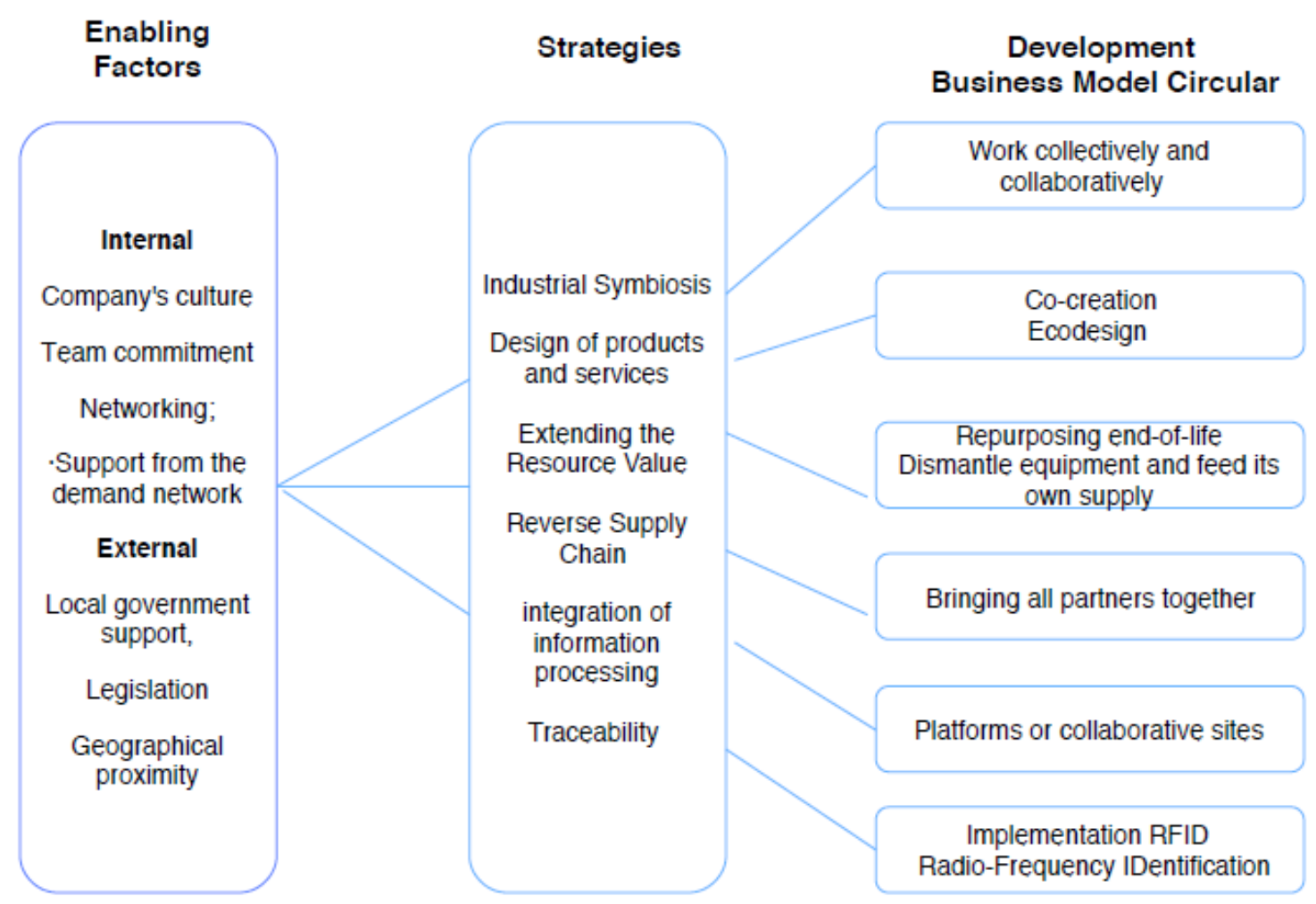

Figure 1. Research framework proposal.

\section{Methodology}

The method adopted for this research is the case study. A case study is one of several ways to conduct social science research. In general, case studies are applied when "how" or "why" questions are proposed; the investigator has little control over the events, and the focus is on a contemporary phenomenon in the context of real life [52]. Thus, through case studies of different industries (electronics and cooling equipment), we sought a thorough understanding of how companies are working to structure their business models from the perspective of a circular economy, with the enabling factors and strategies to be investigated for the development of a circular business model (Table 1). Primary and secondary data were gathered. The primary method of data collection was interviews, complemented by observations and other secondary data to contrast with the interview data. Semi-structured interviews were carried out at different hierarchical levels of the organizations. NVivo software was chosen to support the data analysis, along with the two business models studied. NVivo can be defined as a system of indexing and categorizing unstructured data, allowing for discovery and exploration of the meanings of alphanumeric information, assisting researchers in the course of research with definitions and organization of analytical categories and subcategories in the analysis process. The justification for the use of NVivo is mainly the number of interviews and the need for cross-checks between the results [53]. Data processing in NVivo was divided into three steps: Constructing the database made in the NVivo software, coding and analyzing the data, and preparing 
the research report. In both companies, interviews with professionals were carried out and secondary data were used to compose the case analysis.

Table 1. Summary of enabling factors and strategies for circular business model.

\begin{tabular}{ll}
\hline Enabling factors (internal and external) & Authors \\
\hline Internal & \\
$-\quad \quad$ Company culture & \\
$-\quad \quad$ Team commitment & {$[27,29]$} \\
$-\quad \quad$ Networking & \\
$-\quad$ Support from the demand network & \\
External & \\
$-\quad$ Local government support & {$[30,32]$} \\
$-\quad \quad$ Legislation & \\
$-\quad \quad$ Geographic proximity & Authors \\
\hline Strategies & {$[32]$} \\
\hline Industrial symbiosis & {$[43]$} \\
Design of products and services & {$[33]$} \\
Extending the resource value & {$[35,36]$} \\
Reverse supply chain & {$[46,48,49]$} \\
\hline Integration of information processing and traceability & \\
\hline
\end{tabular}

\subsection{Research Script}

The script was organized and structured from the theoretical framework (described in Section 2, Theoretical Foundation). It was divided into the following parts:

Section A: Establishing the company's general information

Section B: Description of services and products

Section C: Description methods and innovations that managers from this company use to improve the implementation of circular systems

Section D: Structure of the business model

Section E: Enabling factors and strategies adopted to develop the concept of circular business

\subsection{Choice of Enterprises}

Companies were chosen according to the principles and characteristics of the circular economy to promote the creation of value (Table 2), as discussed, listed, and recorded on the Ellen MacArthur Foundation website, the definition proposed by [13], and sustainable business model archetypes discussed by [20]. In their operations, the chosen companies located in Brazil focus on alternative reduction, reuse, recycling, and recovery of materials in the production/distribution and consumption processes. Brazil has unique marketing and social characteristics and unparalleled natural capital. Brazil is an attractive scenario for exploring opportunities that the circular economy could bring to the construction of economic, social and natural capital. The authors of [20] developed archetypes based on a literature review and the practices of business models. Their business models are grouped into three main types of innovative sustainability models: (i) technological, (ii) social, and (iii) organizational. CE strategies are grouped in the technological pillar, within the archetype of "value creation from waste". Companies A and B are aligned to technological pillar. 
Table 2. Profiles of companies with circular model.

\begin{tabular}{clll}
\hline Company & Sector of Activity & \multicolumn{1}{c}{ Services and Products } & \multicolumn{1}{c}{ Features } \\
\hline A & $\begin{array}{l}\text { Commercial } \\
\text { refrigeration }\end{array}$ & $\begin{array}{l}\text { Works with commercial } \\
\text { refrigeration equipment at the end } \\
\text { of life, turning it into new } \\
\text { products, reverse logistics, } \\
\text { and recycling. }\end{array}$ & $\begin{array}{l}\text { Offers solutions and infrastructure } \\
\text { to meet the market's needs of } \\
\text { reverse operation for white-goods } \\
\text { appliances and commercial } \\
\text { refrigeration. } \\
\text { (Business Unit_Startup) }\end{array}$ \\
\hline B & $\begin{array}{l}\text { Electronic } \\
\text { equipment }\end{array}$ & $\begin{array}{l}\text { Uses sustainable solutions for the } \\
\text { use of recycled raw materials and } \\
\text { reverse logistics system. }\end{array}$ & $\begin{array}{l}\text { Integrates eco-sustainable } \\
\text { solutions geared for the consumer } \\
\text { electronics market. } \\
\text { (Business Unit-Startup) }\end{array}$ \\
\hline
\end{tabular}

\subsection{Respondents' Profiles}

The interviews were conducted with at least three professionals in each company (detailed in Table 3), such as managers and other developers linked to the business area, based on the established roadmap. During the interviews, we sought to find more subsidies for a qualitative analysis of the case. The interviews were recorded and transcribed, and reports were prepared with the main points of the interviews, which were sent to the companies to make additional observations. After the transcription and mounting of reports, encoding was adopted, which is one of the recommended first steps to reduce and analyze the collected data [54]. The code must represent the predefined categories and should "match the theoretical properties, unfolded in dimensions associated with the research".

Table 3. Professionals interviewed.

\begin{tabular}{ccclll}
\hline Company & Sector of Activity & & \multicolumn{1}{c}{ Professional Role } & Location of Investigation \\
\hline A & $\begin{array}{l}\text { Commercial } \\
\text { refrigeration }\end{array}$ & - & $\begin{array}{l}\text { General operations manager } \\
\text { Supply chain executive } \\
\text { Sales manager }\end{array}$ & - & Plant of company A \\
& & - & Green IT manager & & \\
B & $\begin{array}{l}\text { Electronic } \\
\text { equipment }\end{array}$ & - & $\begin{array}{l}\text { Sustainability analyst } \\
\text { Sustainability country } \\
\text { manager, Americas }\end{array}$ & - & $\begin{array}{l}\text { Institute of technology of } \\
\text { company B } \\
\text { Plant of company B }\end{array}$ \\
\hline
\end{tabular}

\subsection{Case Study}

\subsubsection{Company A}

Case A is a business unit of a multinational corporation focused on the B2B market of hermetic refrigeration compressors that invests in startups that can provide innovative solutions for customers. Case A, as a startup, presents an independent and lean administrative and operational structure.

Methods and Innovations

The base of case A's business model is to offer reverse logistics solutions for the industry of white-goods appliances, ensuring correct de-characterization and destination of products at the end of their life cycle. Cycle closure by case A is provided with an emphasis on relationships of material capture, with issuance of destination declaration and total information shielding among partners. The materials undergo a process of recovery and transformation, serving as raw material for the development of new products, which benefits the whole chain.

In recent years, the business unit has evolved significantly; it is no longer a project and has become a global business area, acting beyond Brazil as a consulting service provider in Europe and North America. Its consulting firm manages industrial scrap, where all the materials generated in the 
company's production process are mapped in order to generate short-term financial revenue through the rational separation of waste and the development of new partners.

In addition to processing and allocating scrap from refrigerators and other electronic equipment of its customers, the business unit provides a reverse logistics service, assisting clients with National Solid Waste Policy (PNRS) requirements, as demonstrated by the waste manager in the context of electronics (printers), but it emphasizes the confidentiality of the publication on which requirements of the PNRS the refrigerator waste manager assists its customers with.

The correct disposal of discarded products is a necessity that will grow even more when the National Solid Waste Policy comes into force, which will provide shared responsibility for the product life cycle and sectoral agreement for reverse logistics, that is, from the shipment of equipment at the end of its life cycle for Company A's recycling unit.

With this, customers are ensured simple, proper, and safe disposal of discarded products, so that they can focus on their core business, reducing the impact on the environment and generating even more value for the business.

One general manager highlights the scope of operations, stating:

"The operations go far beyond the recycling of materials but rather the aggregation of value of the components and materials aiming at the extension of the life cycle. An example is the reuse of components for manufacturing new products, reindustrialization of components and parts of products as new products in other industries. We call it reuse, reindustrialization, and remanufacturing. We also generate information about field data and waste from our customers after the end of product life."

Strategies Adopted to Develop the Concept of Circular Business

The business is focused on closing the cycle of white-goods appliances and commercial refrigeration at the end of their life cycle. Based on the concepts of circular economy, Company A aims to be a new source of sustainable components and materials for the development of new products for other industries. The focus of the company is to offer solutions and infrastructure to meet the reverse operation needs of the white-goods appliances and commercial refrigeration market. Besides, it also offers recycling and reuse, which provides revenue not only from the provision of reverse logistics services, but also from the sale of recycled raw material and reused products.

Case A is a more sustainable source of raw material for other industries at a time when the waste volume is growing at a rapid pace. There is a worldwide effort by both the private sector and governments to reduce waste generation and promote its correct use, reducing the shipment of products to landfills, and therefore the impact on the environment.

In its laboratories, Company A turns white-goods appliances and commercial refrigerators at the end of their life cycle into new products, adding value to what is nowadays discarded or sold as scrap. Innovation applied in this process actually contributes to a smarter use of these waste products. Related to reverse logistics services, the guarantee of product mischaracterization and technology is paramount. In function of these deliveries, an important factor is reliability of the service provider.

The structure of the company's circular business model is represented in Figure 2. 


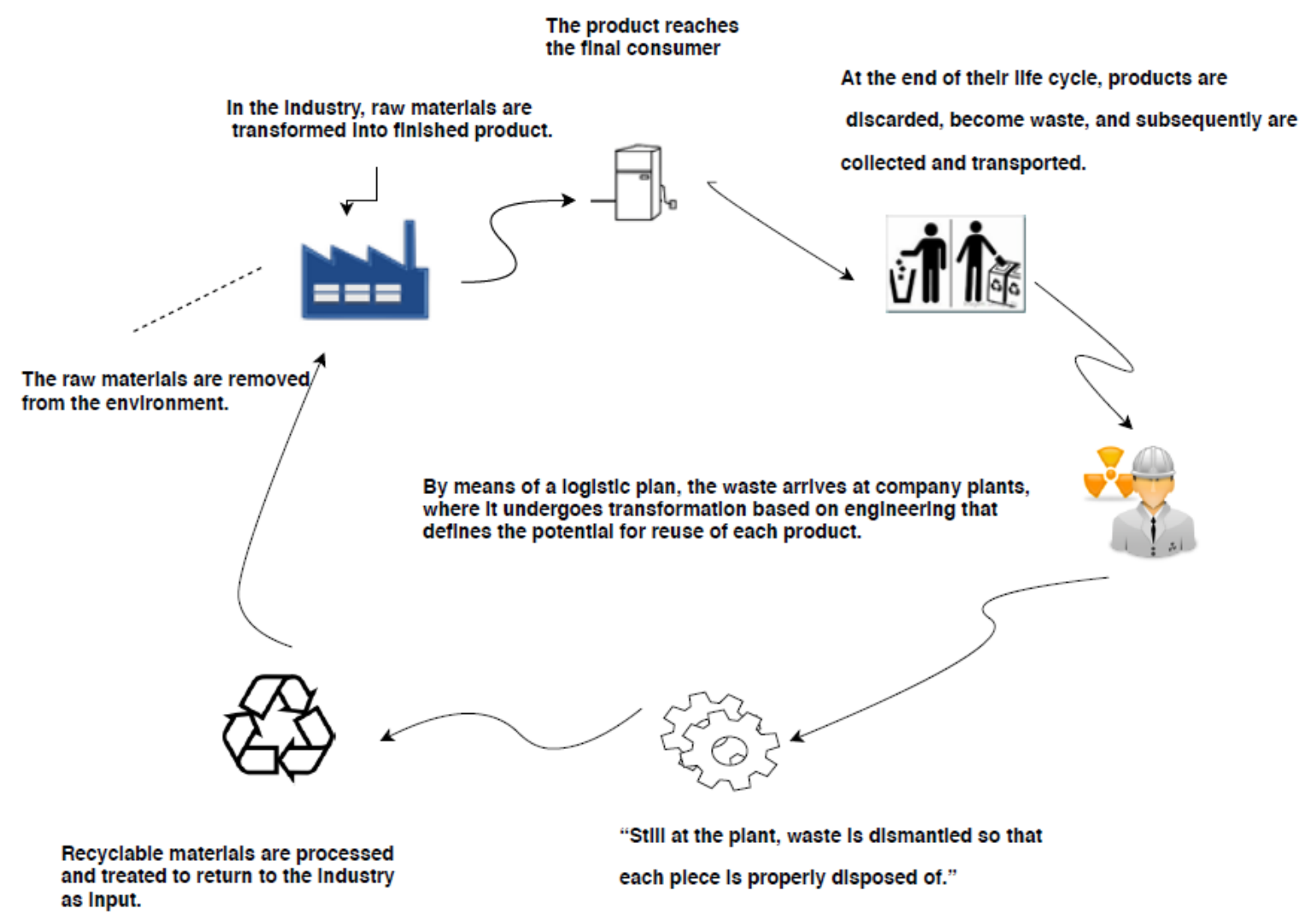

Figure 2. Circular business model: case A.

\subsubsection{Company B}

Case B is a company that has develops infrastructure and technology to collect and transform electronics and raw materials and parts into new products. It was founded in 2010 as a business unit of an American international supply chain solutions company that offers design, manufacturing, distribution, and aftermarket services to original equipment manufacturers (OEMs). After a period of commercial and operational planning and legal and environmental licensing, the plant started operating at the end of 2012.

Methods and Innovations

The company develops sustainable solutions for the use of recycled inputs, reverse logistics systems, recycling centers, and educational programs. In contrast to the traditional linear production model, which spans the extraction of natural resources to the final disposal of post-consumer products, the company adopted a circular process: together with its customers, it uses materials in continuous cycles of manufacturing, use, recovery, dismantling, and remanufacturing. The company seeks to become a sustainability innovation center with several stages of the process of circular economy and reverse logistics. The company is conducting research to improve processes and material quality, implementing industry practices (Six Sigma, lean) and applying productivity- vs. profitability-based product disassembly balancing, as discussed by the Ellen MacArthur Foundation.

\section{Enabling Factors and Strategies Adopted to Develop the Concept of Circular Business}

The company has a sustainable technology innovation center for the electronics industry, completely integrated into the production chain, enabling sustainability as a competitive advantage. In addition to processing its clients' electronic devices scrap, the partnership has a reversal innovation and logistics operation to assist clients in meeting 14 of the 15 PNRS (National Solid Waste Plan) objectives. According to the research, the separation and disassembly process is initially performed by 
models, and the separations are "clustered" in the following parts and pieces: (i) metal components (shipped and sold to companies that recover valuable materials); (ii) covers with labels (shipped to a company that manufactures this type of paper); (iii) ink foam (sold to generate energy in cement manufacture); (iv) cartridge printheads (shipped and sold to companies that recover precious materials); and (v) cartridge and printer bodies (these go through a washing, drying, and grinding process; plastic bottles are then added for the composition of new recycled plastics). The service provider's recycling center also recycles cartridges and printer toners.

The strategy consists of structuring the business model based on Figure 3:

\section{Own Structure}

- $\quad$ Research and development (R\&D)

- $\quad$ Training and qualification

- $\quad$ Institute of technology

- $\quad$ Recycling center

- $\quad$ Standardization and conformity

- $\quad$ Destination and reinsertion of materials

\section{Partner Structure}

- $\quad$ Universities

- $\quad$ Research centers

- Excellence center in radio-frequency identification (RFID) (managed by the company's main client)

- Collection network

- Supplier network

- Consolidation and selection

- Disassembly

Company B works with a focus on:

- Technology and innovation, which includes partnerships with research centers, universities, excellence centers in RFID, with their own structure, focused on training and education, Research and Development (R\&D) and technology (institute of technology).

- Execution, which includes partnerships with networks, supplier networks, companies responsible for disassembly, consolidation, and sorting, with their own recycling structure. 


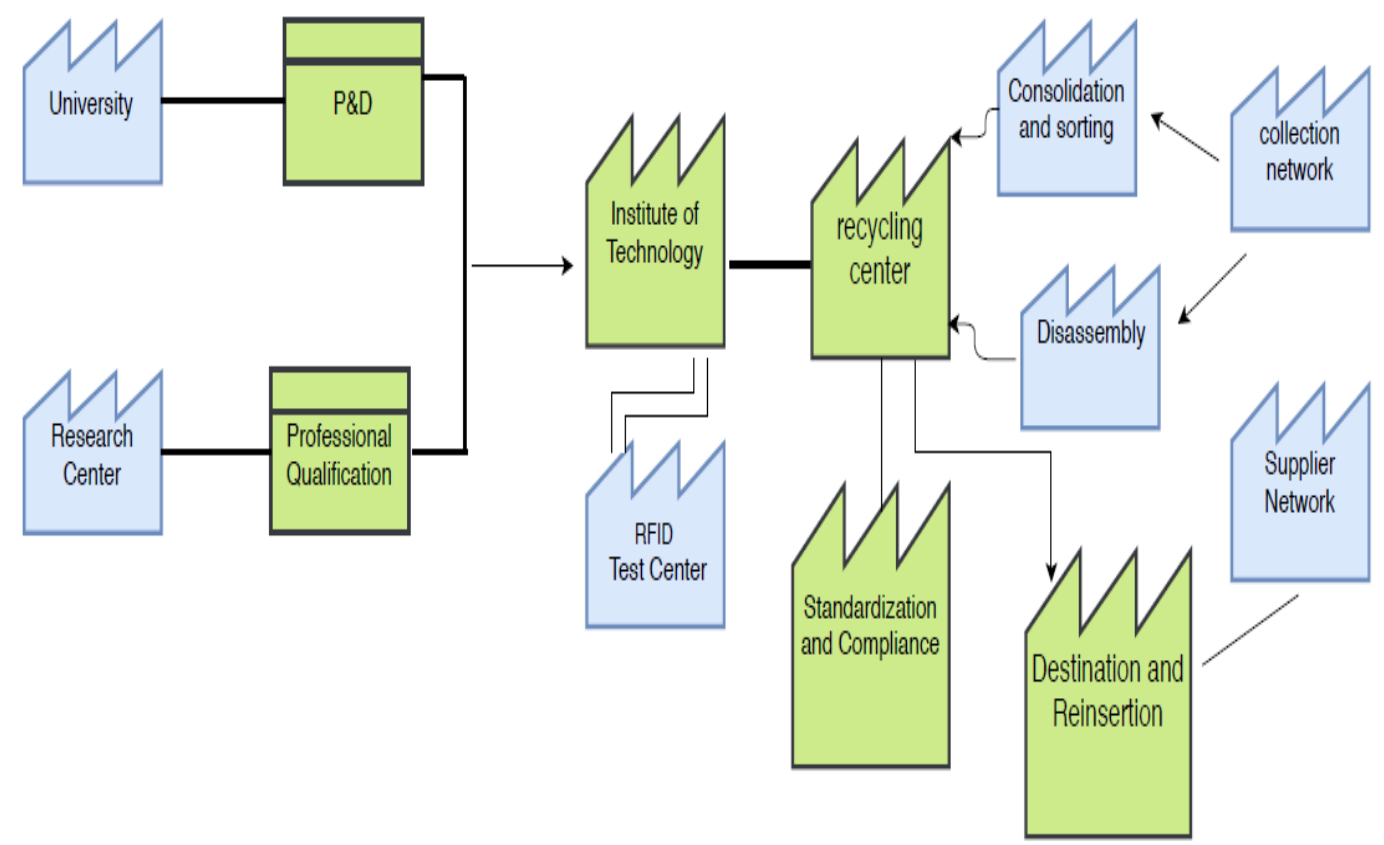

Figure 3. Circular business model: ecosystem of innovation and technology, case B.

\section{Results}

The companies indicated enabling factors aligned to the literature and other factors that can complement studies in this area. Results from the two cases indicated the following additional factors: in-house laboratory, expertise and capabilities needed to convert to the idea of a circular economy, proximity to government agencies and constant communication, stakeholder support, and feedback loops. Both companies are business units with independent organizational structure and offer reverse logistics, recycling, and reuse solutions.

Case $\mathrm{A}$ is a business unit of a large company in the white-goods appliances industry that has strategic fronts for new business development in different areas. One of the focus areas of development is related to household appliances recycling. The company that developed the business model (case A) has in its DNA an innovation strategy as a pillar of growth and sustainability for its business as a whole. Case A is focused on recovering all the potential value of waste from electrical and electronic equipment, to extend the usefulness of end-of-life products to the maximum, becoming a supplier of parts and materials or seeking environmentally appropriate solutions for waste disposal. Case A intends to become a strategic partner of manufacturers to deal with end-of-life products as required by the National Solid Waste Policy (PNRS). The company adopts high-quality standards for reverse manufacturing, which include lean manufacturing and Six Sigma methodologies. Case A develops partnerships and offers $R \& D$ services to customers to find the most profitable ways to recover the value of end-of-life products. Its business model does not include repairing or remanufacturing products. The manufacturer pays for the product collection service performed by the reverse logistics developed by the company. In general, door-to-door collection of final consumer products is not economically viable. The main weakness found in the business model of case $\mathrm{A}$ is uncertainty about the recovery of parts to ensure a stable supply to buyers of recycled materials and reused parts. The visual appearance of recovered parts is an obstacle to sales, so the commercialization of parts to be reused within new products is more feasible.

Case B started as an enabling agent for an initiative of collecting and recycling for a large electronics client and has since expanded to a solution that covers value chains, operating 400 collection points in all Brazilian states. The business model was developed from a partnership with the company that had a strategy related to sustainable development. In 2008, two companies in the technology sector formed a partnership in manufacturing to identify the chances of recovering materials from end-of-life 
products. Distribution coordination, local suppliers, and an internal network of professionals were key elements in the collaboration. This partnership culminated in the creation of an innovation center operated by company B. Collaboration with universities, sectors, retailers, social organizations, and logistics operators is another essential part of the model. The collaborative model developed by case B has allowed the creation of an integrated ecosystem of sustainable solutions aimed at the electronics market: it integrates reverse logistics, materials processing, and research and development investments in search of new uses for received components, also ensuring the quality of the produced material and enabling customers to access this infrastructure for their research.

In interviews, general managers at company B mentioned that suppliers are recognized as strategic partners who help to achieve results, and to make sure suppliers are engaged and committed, they maintain personal contact with face-to-face meetings to align expectations and tasks and facilitate relevant information sharing. In addition, the business model designed by company B seeks to add more value to recycled plastic through investment in process, recycling practices, and material development. Its goal is to provide the electronic industry with $100 \%$ recycled plastic with similar physical and chemical characteristics as virgin material, actually closing the supply chain for this vital raw material.

Companies A and B highlighted that the R\&D internal laboratory is fundamental to the production of materials and components that meet the industry's quality standards and various customers' needs. In addition to the traditional concerns with design, functional characteristics, quality, and cost, it is necessary to add requirements for the use of recycled and recyclable nonhazardous materials, with the possibility of easy disassembly, and the reuse of parts and raw material. That is what they call "design for environment" or "design for recycling", which are essential for sustainability. Cases A and B have evidenced the importance of the proximity between manufacturing and consumer markets.

The interviews were coded taking into account the concepts worked on in this study. Nodes (or categories) generated by NVivo contain the parts of texts that have been encoded. The occurrences were divided into categories according to Table 4, which presents a summary of the results for each case. Tables 4 and 5 show the strategies and enabling factors identified in the literature, as well as those observed through the empirical studies.

Table 4. Summary of the results: strategies.

\begin{tabular}{|c|c|c|c|}
\hline Strategies & Case A & Case B & Literature \\
\hline $\begin{array}{l}\text { Intersectoral } \\
\text { collaboration/partnerships/ } \\
\text { supplier Engagement }\end{array}$ & $\begin{array}{l}\text { Highlights partnerships, but not } \\
\text { characterized as an ecosystem } \\
\text { linked to sustainability as case B }\end{array}$ & $\begin{array}{l}\text { Participates in a partners network, } \\
\text { establishing an ecosystem of } \\
\text { innovation and technology }\end{array}$ & $\begin{array}{l}\text { Ecosystem strategy } \\
\text { emerged from the case B } \\
\text { study research }\end{array}$ \\
\hline $\begin{array}{l}\text { Technology-laboratory } \\
\text { structure and interaction } \\
\text { with universities }\end{array}$ & $\begin{array}{l}\text { Evidences the development of } \\
\text { technology and innovation of } \\
\text { laboratory structure and researchers, } \\
\text { interaction with universities }\end{array}$ & $\begin{array}{l}\text { Showed the development of a } \\
\text { sustainable innovation center } \\
\text { (laboratory) and interaction with } \\
\text { universities and the development } \\
\text { of joint products }\end{array}$ & $\begin{array}{l}\text { Strategy related to } \\
\text { interaction with } \\
\text { universities emerged } \\
\text { from the case study } \\
\text { research }\end{array}$ \\
\hline $\begin{array}{l}\text { Strategies for circular } \\
\text { product design }\end{array}$ & Design for "technological cycle" & $\begin{array}{l}\text { Projects developed with } \\
\text { universities and research centers; } \\
\text { design processes and expansion of } \\
\text { service models and performance }\end{array}$ & Aligned to [45] \\
\hline
\end{tabular}


Table 5. Summary of the results: enabling factors.

\begin{tabular}{llll}
\hline \multicolumn{1}{c}{ Enabling Factors } & \multicolumn{1}{c}{ Case A } & \multicolumn{1}{c}{ Case B } & \multicolumn{1}{c}{ Literature } \\
\hline Legislation: PNRS & $\begin{array}{l}\text { Drives the development of the } \\
\text { business unit to comply } \\
\text { with legislation }\end{array}$ & $\begin{array}{l}\text { Encourages its partners to } \\
\text { adopt processes to comply } \\
\text { with the legislation }\end{array}$ & $\begin{array}{l}\text { Factor emerged from the } \\
\text { literature [27,28] }\end{array}$ \\
\hline Organizational culture & $\begin{array}{l}\text { Ease of adopting the principles of the } \\
\text { circular economy by an independent } \\
\text { business unit }\end{array}$ & $\begin{array}{l}\text { Ease of adopting principles of } \\
\text { the circular economy by an } \\
\text { independent business unit }\end{array}$ & $\begin{array}{l}\text { Factor emerged from the } \\
\text { literature [27] }\end{array}$ \\
\hline $\begin{array}{l}\text { New organizational routines } \\
\text { and processes }\end{array}$ & $\begin{array}{l}\text { Automation of dismantling processes } \\
\text { that allow a reduction in conversion } \\
\text { costs, allowing a reduction of costs } \\
\text { and leveraging the growth } \\
\text { strategy Operation }\end{array}$ & $\begin{array}{l}\text { New processes were created, } \\
\text { people empowered, } \\
\text { and machinery acquired }\end{array}$ & $\begin{array}{l}\text { Factor emerged from the } \\
\text { case study research }\end{array}$ \\
\hline $\begin{array}{l}\text { Independent business unit } \\
\text { of a large company }\end{array}$ & Evidenced by case A & Evidenced by case B & $\begin{array}{l}\text { Factor emerged from the } \\
\text { case study research }\end{array}$ \\
\hline
\end{tabular}

\section{Results Discussion}

For both case A and case B, the integration strategy in the supply chain and the proximity between the manufacturing and the consumer market make the circular economy project aligned to [30]. The results are in agreement with [39], who emphasize the importance of aligning the supply chains as an important strategy for organizations to work in the context of the circular economy. Aligned to [38], managers highlight collaboration as a key element for the development of a circular business model.

Cases $\mathrm{A}$ and $\mathrm{B}$ are business units of large companies with independent performance and organizational structures. Aligned to [28], companies A and B emphasized that the enabling factor for investment in the circular model was the need to adopt the National Solid Waste Policy (PNRS), which establishes shared responsibility of waste generators from manufacturers to final consumers, in reverse logistics of waste and postindustrial and postconsumer packaging. Due to the environment where company A is situated (a startup of a multinational company in the white-goods appliances sector), it was observed that access to knowledge of the involved technologies allowed an opportunity to expand and develop the idea that at the beginning it would only be an adequacy action plan influenced by the external environment, issues related to the legislation. Company A went on to treat the sustainability theme as a source of revenue and an additional high-value service that could be offered to its customers. Company B was a viable agent of a partner that was seeking to meet the PNRS, a large company in the technology sector that sought to execute a corporate waste reduction project, which was the starting point for the development of its business model. Companies are active in the life cycle of their products, realizing the cradle-to-grave cycle.

As mentioned before, company $B$ is a business unit of a large company that utilizes its expertise and capabilities to develop the circular business model. Thus, company B applies its knowledge of manufacturing to dismantle equipment and feed its own supply chain.

In order to improve the solid waste management situation, the PNRS was approved in Brazil in 2010. The policy establishes guidelines for the implementation and management of reverse logistics systems in the country. The PNRS has a horizon of 20 years for full implementation, and should be updated every four years. Consideration should be given to diagnosing the current situation of solid waste and proposed scenarios related to international trends and macroeconomic indicators. Plans should include a diagnosis and goals, as well as programs, projects, and actions to be implemented in accordance with the PNRS.

- Theoretical Implications

The theoretical contribution of the study consists of delivering a roadmap with the enabling factors and strategies from the literature, but also with factors identified from the case study. The following factors and strategies emerged that were not already approached in the literature:

- Developing business units linked to large multinational companies, yet having an independent organizational structure, being financially sustainable for both cases A and B 
- Dismantling equipment and feeding their own supply

- Creating new organizational routines independent of the companies that they are linked to

- Developing ecosystems based on reverse logistics, recycling facilities, research and development, and reverse supply chains

Company B highlights as a strategy a business ecosystem, which can be understood as a dynamic structure consisting of interconnected enterprises, for example through research partnerships, supplier contracts, and information exchange. The business ecosystem is formed by firms that adopt different roles that contribute in various ways to the stability and productivity of the system. Understanding the elements and dynamics that govern a business ecosystem is very important for consolidation of the strategy, since it is understood that this allows a reliable projection of the expectations about the business that is being undertaken. In this context, it is important to design organizational mechanisms so that business innovation takes place in real time as the ecosystem evolves.

It should be noted that large companies are being inserted in the circular economy through a business model that is constituted as an independent unit. The partnerships and service negotiations directly impact the bargaining power with suppliers, constituting a viable factor identified in the empirical study developed in this research. This study contributes to a better understanding of the strategies adopted by companies for the development of a business model, as well as the respective enabling factors.

- Managerial Implications

The study contributes to the formulation and strategic planning of a business model in the context of the circular economy. Identifying the feasibility factors and strategies adopted by the companies allows managers to reflect on the process of making a business model viable in the context of the circular economy, allowing them to establish the factors that companies have to develop for a successful business model. Additionally, the details of the practices presented in the study include implementation analysis and are instructive for managers. It should be noted that both cases showed favorable economic results.

\section{Conclusions}

This study allows us to discuss a business model that has as its central strategy the principles of circular economy, in which all the materials can be reused in other industrial processes, thereby reducing the consumption of natural resources. Constructing a circular model involves several actors, challenges, and barriers. The analyzed companies are established in different sectors, and the results indicate that factors such as industrial symbiosis, collaboration, and technology are present, as reflected in the interviews. Developing an infrastructure for logistics is important for the development of a circular business model. Discussing these enablers is important in developing a circular economy allowing sustainability to be embedded into business purpose and processes and serve as a key driver of competitive advantage.

Companies need to focus on reducing unnecessary resources and think more about how to keep materials and products in the loop as long as possible. In order to do this, they need to find new collaboration partners and reconsider the value offered to their stakeholders. To solve this, new tools and process innovations are needed to guide companies on their innovation journey; this will result in new business models in a circular economy. This theme has several unfolding perspectives for future research; for example, more detailed case study research related to ecosystems, focusing on collaboration, would reveal more insights into the intentions, contributions, and strategic objectives of the involved parties. 
Author Contributions: C.A.M. and T.L.M.A. contributed to the study presented in this paper.

Funding: This study was financed in part by the Coordenação de Aperfeiçoamento de Pessoal de Nível Superior-Brasil (CAPES)-Finance Code 001.

Conflicts of Interest: The authors declare no conflict of interest.

\section{References}

1. Ness, D. Sustainable urban infrastructure in China: Towards a Factor 10 improvement in resource productivity through integrated infrastructure system. Int. J. Sustain. Dev. World Ecol. 2008, 15, 288-301.

2. Singh, J.; Ordoñez, I. Resource recovery from post-consumer waste: Important lessons for the upcoming circular economy. J. Clean. Prod. 2016, 134, 342-353. [CrossRef]

3. Ellen MacArthur Foundation. Towards the Circular Economy: Economic and Business Rationale for an Accelerated Transition. Available online: http:/ / mvonederland.nl/system/files/media/towards-thecircular-economy.pdf (accessed on 15 January 2017).

4. Feng, Z.; Yan, N. Putting a circular economy into practice in China. Sustain. Sci. 2007, 2, 95-101.

5. Naustdalslid, J. Circular economy in China-The environmental dimension of the harmonious society. Int. J. Sustain. Dev. World Ecol. 2014, 21, 303-313. [CrossRef]

6. Mathews, J.A. Naturalizing capitalism: The next Great Transformation. Futures 2001, 43, 868-879. [CrossRef]

7. Scheepens, A.E.; Vogtländer, J.G.; Brezet, J.C. Two life cycle assessment (LCA) based methods to analyse and design complex (regional) circular economy systems. Case: Making water tourism more sustainable. J. Clean. Prod. 2016, 114, 257-268. [CrossRef]

8. Zink, T.; Geyer, R. Circular Economy Rebound. J. Ind. Ecol. 2017, 21, 593-602. [CrossRef]

9. Gregson, N.; Crang, M.; Fuller, S.; Holmes, H. Interrogating the circular economy: The moral economy of resource recovery in the EU. Econ. Soc. 2014, 42, 218-243. [CrossRef]

10. Scott, J.T. The Sustainable Business a Practitioner's Guide to Achieving Long-Term Profitability and Competitiveness, 2nd ed.; Greenleaf Publishing: Sheffield, UK, 2015.

11. Witjes, S.; Lozano, R. Towards a more Circular Economy: Proposing a framework linking sustainable public procurement and sustainable business models. Resour. Conserv. Recycl. 2016, 112, 37-44. [CrossRef]

12. Van Buren, N.; Demmers, M.; van der Heijden, R.; Witlox, F. Towards a Circular Economy: The Role of Dutch Logistics Industries and Governments. Sustainability 2016, 8, 647. [CrossRef]

13. Kirchherr, J.; Reike, D.; Hekkert, M. Conceptualizing the circular economy: An analysis of 114 definitions. Resour. Conserv. Recycl. 2017, 127, 221-232. [CrossRef]

14. Schaltegger, S.; Hansen, E.G.; Lüdeke-Freund, F. Business models for sustainability: Origins, present research, and future avenues. Organ. Environ. 2016. [CrossRef]

15. Van Renswoude, K.; Wolde, A.T.; Joustra, D.J. Circular Business Models. Part 1: An introduction to IMSA's Circular Business Model Scan. Available online: https:/ groenomstilling.erhvervsstyrelsen.dk/sites/ default/files/media/imsa_circular_business_models_-_april_2015_-_part_1.pdf (accessed on 25 July 2017).

16. Ghisellini, P.; Cialani, C.; Ulgiati, S. A review on circular economy: The expected transition to a balanced interplay of environmental and economic systems. J. Clean. Prod. 2016, 114, 11-32. [CrossRef]

17. Lewandowski, M. Designing the Business Models for Circular Economy-Towards the Conceptual Framework. Sustainability 2016, 8, 43. [CrossRef]

18. Pateli, A.G.; Giaglis, G.M. A research framework for analysing eBusiness models. Eur. J. Inf. Syst. 2004, 13, 302-314. [CrossRef]

19. Wirtz, B.W. Business Model Management: Design—Instruments—Success Factors, 1st ed.; Springer: Dordrecht, The Netherlands, 2011.

20. Bocken, N.M.; Short, S.W.; Rana, P.; Evans, S. A literature and practice review to develop sustainable business model archetypes. J. Clean. Prod. 2014, 65, 42-56. [CrossRef]

21. Linder, M.; Williander, M. Circular Business Model Innovation: Inherent Uncertainties. Bus. Strateg. Environ. 2015, 26, 182-196. [CrossRef]

22. Bocken, N.M.; de Pauw, I.; Bakker, C.; van der Grinten, B. Product design and business model strategies for a circular economy. J. Ind. Prod. Eng. 2016, 33, 308-320. [CrossRef]

23. Lieder, M.; Rashid, A. Towards circular economy implementation: A comprehensive review in context of manufacturing industry. J. Clean. Prod. 2016, 115, 36-51. [CrossRef] 
24. Laubscher, M.; Marinelli, T. Integration of Circular Economy in Business. In Proceedings of the Conference: Going Green-CARE INNOVATION 2014, Vienna, Austria, 17-20 November 2014.

25. Wynstra, F.; Axelsson, B.; Van Weele, A. Driving and enabling factors for purchasing involvement in product development. Eur. J. Purch. Supply Manag. 2000, 6, 129-141. [CrossRef]

26. Ma, L.; Song, W.; Zhou, Y. Modeling enablers of environmentally conscious manufacturing strategy: An integrated method. Sustainability 2018, 10, 2284. [CrossRef]

27. Rizos, V.; Behrens, A.; Van Der Gaast, W.; Hofman, E.; Ioannou, A.; Kafyeke, T.; Topi, C. Implementation of circular economy business models by small and medium-sized enterprises (SMEs): Barriers and enablers. Sustainability 2016, 8, 1212. [CrossRef]

28. Luken, R.; Rompaey, F.V. Drivers for and barriers to environmentally sound technology adoption by manufacturing plants in nine developing countries. J. Clean. Prod. 2008, 16, 67-77. [CrossRef]

29. Oghazi, P.; Mostaghel, R. Circular Business Model Challenges and Lessons Learned-An Industrial Perspective. Sustainability 2018, 10, 739. [CrossRef]

30. Chertow, M.R. Industrial symbiosis: Literature and taxonomy. Annu. Rev. Energy Environ. 2000, $25,313-337$. [CrossRef]

31. De Abreu, M.C.S.; Ceglia, D. On the implementation of a circular economy: The role of institutional capacity-building through industrial symbiosis. Resour. Conserv. Recycl. 2018, 138, 99-109. [CrossRef]

32. Ayres, R.; Simonis, U. (Eds.) Industrial Metabolism: Restructuring for Sustainable Development; United Nations University Press: Tokyo, Japan, 1994.

33. Short, S.; Bocken, N.; Barlow, C.; Chertow, M. From refining sugar to growing tomatoes. Industrial ecology and business model evolution. J. Ind. Ecol. 2014, 18, 603-618. [CrossRef]

34. Vanegas, P.; Peeters, J.R.; Cattrysse, D.; Tecchio, P.; Ardente, F.; Mathieux, F.; Dewulf, W.; Duflou, J.R. Ease of disassembly of products to support circular economy strategies. Resour. Conserv. Recycl. 2018, 135, 323-334. [CrossRef]

35. Masi, D.; Day, S.; Godsell, J. Supply Chain Configurations in the Circular Economy: A Systematic Literature Review. Sustainability 2017, 9, 1602. [CrossRef]

36. Nasir, M.H.A.; Genovese, A.; Acquaye, A.A.; Koh, S.C.L.; Yamoah, F. Comparing linear and circular supply chains: A case study from the construction industry. Int. J. Prod. Econ. 2017, 183, 443-457. [CrossRef]

37. Genefke, J. Collaboration costs. In Collaboration Strategies and Multi-Organizational Partnerships; Tallieux, T., Ed.; Garant: Leuven-Apeldoorn, Belgium, 2001.

38. Franco, M.A. Circular economy at the micro level: A dynamic view of incumbents' struggles and challenges in the textile industry. J. Clean. Prod. 2017, 168, 833-845. [CrossRef]

39. Genovese, A.; Acquaye, A.A.; Figueroa, A.; Koh, S.L. Sustainable supply chain management and the transition towards a circular economy: Evidence and some applications. Omega 2017, 66, 344-357. [CrossRef]

40. Govindan, K.; Soleimani, H.; Kannan, D. Reverse logistics and closed-loop supply chain: A comprehensive review to explore the future. Eur. J. Oper. Res. 2014, 2014, 603-626. [CrossRef]

41. Zhou, C.; Zhang, P. Research on Reverse Logistics System Base on Circular Economy. In Proceedings of the 2007 International Conference on Wireless Communications, Networking and Mobile Computing, Shanghai, China, 21-25 September 2007; pp. 3744-3746.

42. Rashid, A.; Asif, F.M.; Krajnik, P.; Nicolescu, C.M. Resource Conservative Manufacturing: An essential change in business and technology paradigm for sustainable manufacturing. J. Clean. Prod. 2013, 57, 166-177. [CrossRef]

43. Goyal, S.; Sergi, B.S.; Jaiswal, M. How to design and implement social business models for base-of-the-pyramid (BoP) markets? Eur. J. Dev. Res. 2015, 27, 850-867. [CrossRef]

44. Moreno, M.; De los Rios, C.; Rowe, Z.; Charnley, F. A Conceptual Framework for Circular Design. Sustainability 2016, 8, 937. [CrossRef]

45. Coughlan, D.; Fitzpatrick, C.; McMahon, M. Repurposing end of life notebook computers from consumer WEEE as thin client computers-A hybrid end of life strategy for the Circular Economy in electronics. J. Clean. Prod. 2018, 192, 809-820. [CrossRef]

46. Gassmann, O.; Frankenberger, K.; Csik, M.; Weiblen, T. The 4I-framework of business model innovation: A structured view on process phases and challenges. Int. J. Prod. Dev. 2013, 18, 249-273. 
47. Adams, K.; Osmani, M.; Thorpe, T.; Thornback, J. Circular economy in construction: current awareness, challenges and enablers. Available online: https://dspace.lboro.ac.uk/dspace-jspui/bitstream/2134/24136/ 3/jwarm.16.00011.pdf (accessed on 25 July 2018).

48. Velte, C.J.; Steinhilper, R. Complexity in a Circular Economy: A Need for Rethinking Complexity Management Strategies. In Proceedings of the World Congress on Engineering, London, UK, 29 June-1 July 2016.

49. Jabbour, C.J.C.; de Sousa Jabbour, A.B.L.; Sarkis, J.; Godinho Filho, M. Unlocking the circular economy through new business models based on large-scale data: An integrative framework and research agenda. Technol. Forecast. Soc. Chang. 2017. [CrossRef]

50. Teece, D.J. Business models, business strategy and innovation. Long Range Plan. 2010, 43, 172-194. [CrossRef]

51. Zott, C.; Amit, R. Business model design: An activity system perspective. Long Range Plan. 2010, 43, $216-226$. [CrossRef]

52. Yin, R.K.; Estudo de Caso: Planejamento e Métodos. Bookman Editora. Available online: https:/ / saudeglobaldotorg1. files.wordpress.com/2014/02/yin-metodologia_da_pesquisa_estudo_de_caso_yin.pdf (accessed on 25 July 2018).

53. Gibbs, G. Qualitative Data Analysis: Explorations with NVivo (Understanding Social Research); Open University Press: Buckingham, UK, 2002.

54. Voss, C.; Tsikriktsis, N.; Frohlich, M. Case Research in Operations Management. Int. J. Oper. Prod. Manag. 2002, 22, 195-219. [CrossRef]

(C) 2018 by the authors. Licensee MDPI, Basel, Switzerland. This article is an open access article distributed under the terms and conditions of the Creative Commons Attribution (CC BY) license (http://creativecommons.org/licenses/by/4.0/). 